Nadine Normand-Marconnet* and Joseph Lo Bianco

\title{
The Common European Framework of Reference down under: A survey of its use and non-use in Australian universities
}

DOI 10.1515/cercles-2015-0014

Abstract: Today, the Common European Framework of Reference for Languages (CEFR; Council of Europe 2001) is widely recognised as emblematic of globalization in education, both in the realms of policy and in educational practice (Byram et al. 2012a). In Europe the CEFR is regularly cited as a reference point for curriculum planning, and is often claimed to support greater transparency and coherence across the entire spectrum of language education. Despite substantial adoption of the CEFR beyond Europe, it has gained little ground in Australian higher education institutions. In order to understand this anomaly, and to analyse the underlying causes of the low traction the CEFR commands in Australia, this article reports on a study of the attitudes, knowledge and perceptions of academics and students collected through a nationwide online survey. The results suggest a perplexing situation, a combination of general unfamiliarity contrasted with pockets of positive acceptance of the CEFR in Australian universities. Moreover, the data suggest that respondents who are teachers are rather less concerned by claimed impediments to learning standards than some researchers and applied linguists who have made such criticism of the CEFR. The article also discusses some controversies that surround attempts to promote the CEFR for wider use. The aim is to contribute to local and international debate on the CEFR and to stimulate discussion about the roles and limits of its use as a universal language learning reference document and as a practical resource to support language teaching and assessment.

Keywords: Common European Framework of Reference for Languages (CEFR), higher education, Australia, language learning, language assessment

\footnotetext{
*Corresponding author: Nadine Normand-Marconnet, School of Languages, Literatures, Cultures and Linguistics, Monash University, Australia, E-mail: nadine.normandmarconnet@monash.edu Joseph Lo Bianco, Graduate School of Education, University of Melbourne, Australia, E-mail: j.lobianco@unimelb.edu.au
} 


\section{Introduction}

Today, the Common European Framework of Reference for Languages (CEFR) is widely acclaimed as an emblem of globalization in education, a key instance of international collaboration in educational policy and practice (Byram et al. 2012a). As stated in the introduction, the CEFR provides "a common basis for the elaboration of language syllabuses, curriculum guidelines, examinations, textbooks, etc. across Europe" (Council of Europe 2001: 1). The action-oriented and language-independent character of the CEFR has found favour within its original European context, having been adopted in 30 of the 47 member states of the Council of Europe. Despite such widespread implementation across Europe, and substantial influence beyond Europe, the CEFR has gained little ground in Australia. In order to understand this anomaly, and to analyse the underlying causes of the low traction the CEFR commands in Australia, this article reports on a study of the attitudes, knowledge and perceptions of academics and students collected through a nationwide online survey. In the course of discussing the results of the survey and a review of relevant literature, the aim of the article is to contribute to debate on the CEFR and stimulate discussion about the roles and limits its use as a universal language learning reference document and as a practical resource to support language teaching and assessment.

\section{Increasing debates around the influence of the CEFR}

As of August 2014 thirty-nine language versions of the CEFR were available. Numerous papers and books describe its impact in specific contexts of its incorporation into the curriculum, assessment and teaching practices of diverse education systems. For the most part the adoption of the CEFR has been through the independent initiative of local governmental agencies and policymakers. For example, there are well documented analyses of pilot projects mainly aiming at the alignment of curricula on the CEFR proficiency scale on the American continent, with studies conducted in Argentina (Porto 2012), Canada (Vandergrift 2006; Faez et al. 2012; Wernicke and Bournot-Trites 2012), Colombia (López Mendoza and Janssen 2011; de Mejía 2012), Mexico (Despagne and Grossi 2011), and the United States (Byrnes 2012). Several Asian countries have been actively involved in adaptation/localisation of the CEFR and scholarly reports of these experiences are available from China (Rong 2010) and specifically related to adaptation of the CEFR for the Chinese language (Bellassen and Zhang 2008), in 
Japan (Noriyuki 2009; O’Dwyer and Nagai 2011) and for Japanese (Suzuki and Togashi 2013), in Korea (Finch 2009), and in Taiwan (Wu and Wu 2007; Wu 2012). By contrast there are few articles documenting adaptation or adoption of CEFR from the Middle East and related contexts like Turkey (Glover 2011; Üstünlüoğlu et al. 2012) and Iran (Normand-Marconnet 2013). However, some of these articles focus on particular aspects of implementation such as use of CEFR descriptors to stimulate reflective learning. It appears that there is no substantial published evaluation of use of the CEFR in African settings. Only sparse literature exists on the CEFR in New Zealand and Australia, as discussed in the following section.

This evidence of widespread influence of the CEFR, however, is not without contestation or at least debate as to its merits and value. Soon after its publication in Europe the Framework was subjected to severe criticism, directed at both theoretical and political aspects of its implementation. One particularly important example was a 2004 debate launched in the Guardian newspaper by Glen Fulcher, Professor of Education and Language Assessment at Leicester University, who argued that implementation of the CEFR could lead European countries to devise and build tests from an "unsafe" basis, due, he claimed, to the lack of relevance and validity of CEFR level descriptors in second language acquisition (SLA) (Fulcher 2004). In response, the Dutch CEF Construct Project (Alderson et al. 2006) subsequently pointed out that the descriptors provided in the CEFR perform a limited function, and should only serve as a starting point for specifying test content. This debate highlights contrasting positions within the field of professional language testing, brought about by a not always rigorous adoption of the CEFR by influential commercial agencies, provoking concerns among higher education language testing specialists. Similarly, other points of criticism were generated within the field of SLA theory, with experts expressing concern about the validity and reliability of scales used in the development processes of assessment systems (Hulstijn 2007) based on the lack of sufficient detail supporting test specification. This position lead to the Council of Europe (2007) response, which aimed to "rectify imbalances in interpretation and use" (Byram et al. 2012b: 5). The most extreme criticism, both trenchant and rather polemical, levelled at the CEFR, especially related to its expansion beyond European settings, was that it represents "another instance of linguistic imperialism" (McBeath 2011: 208).

Some criticisms have related to misuse, rather than alleged design flaws, or political aspects of the spread of CEFR. Little (2007), for example, points out the inadequacy of level descriptors in the CEFR for learning contexts in which content and language are fused, such as occurs in Content and Language Integrated Learning (CLIL) teaching programs, and Krumm (2007) makes a related argument about the inadequacy of level descriptors in programs that teach national 
languages to immigrant populations. Misuse has also been reported in administration of the CEFR such as inappropriate recruitment assessment practices in corporate outsourcing in India and the Philippines (Lockwood 2012).

In response to such controversies and critiques, the authors of the CEFR and their supporters highlight the inherent "flexibility" of the Framework and reiterate the need for careful adherence to its intended uses, and rally against instances of misuse (North 2014; Coste 2007; Little 2007). Specifically, Fleming (2006) responds to the criticism that the CEFR exhibits a limited or narrow-base language theory by pointing out that, while can do statements are often viewed by critics of the CEFR as narrow, functionalist, or even behaviourist in their inspiration, "competence frameworks have the potential to focus on the importance of use and purpose, implying a more dynamic rather than static concept of language” (Fleming 2006: 54). In 2007 Davidson and Fulcher developed a specific descriptor for service encounter specification from the generic model provided by the CEFR at Level A1 and found it "a valuable starting point for language test development” (2007: 231). Jones and Saville later conducted a project that called for "the need to develop contextualized, practical ways of realizing the CEFR's potential as a framework for teaching and learning” (2009: 51). Finally, as Trim has remarked, "the Framework should be flexible, open, dynamic and non-dogmatic, since the aim was not to prescribe how languages should be learnt, taught and assessed, but to raise awareness, stimulate reflection and improve communication among practitioners" (2012: 29-30). In addition, the European Language Portfolio (ELP) was developed in order to encourage a more learner-centred approach to language teaching and learning, a core principle in the CEFR. While the ELP Validation Committee assessed and accredited 118 ELPs from 33 member states and 6 international consortia and International Non-Governmental Organisations between 2000 and 2010 (Little et al. 2011), the companion tool of the CEFR has never been widely used anywhere in Europe. Overall, the impact of the CEFR on curriculum development has not been significant, despite the scattered engagement of some individuals or institutions around the world. One might summarise by saying that the CEFR has succeeded in garnering a substantial presence in education, and is often acclaimed by its defenders as an efficient mechanism for achieving a desired international harmonisation in the field of assessment (Weir 2005).

\section{An overview of language policy in Australia}

Any claims regarding the relevance of the CEFR in Australia, and especially the most vaunted claim that it is both an effective and reliable reference to develop strategic language policy and a practical resource for teaching and assessment, 
must be examined against the backdrop of the specific communicative context and language policy settings that prevail in the country. Australia is characterised by a high degree of multilingualism and multiculturalism, with a long and complicated history of policy responses to its domestic linguistic pluralism and its geographic context, through a series of developments in language policy (LP). In this context, Lo Bianco (2004) has identified five broad LP phases. The first is Britishism, which, from the establishment of the British convict and later settler societies from the end of the 18th century, characterized most of the colonial and early national period of Australian history, during which language policy consisted mainly of defence and promotion of English, modelled on Southern British norms. Only prestige foreign languages were taught, mostly in elite schools or universities, but in a limited way. The choice of languages and the methodologies of their teaching typically mirrored those found in British public schools (especially Latin, whose teaching was premised on the idea of a universal "mental training” and access to classical literature, as well as French, followed by German, with a later and much smaller presence of Italian). In contrast to the dominant educational practices, the wider population was always highly multilingual, both the pre-colonial indigenous community and the immigrant-derived population, marred by many instances of linguistically repressive policies.

Nationalist agitation for political independence and the gradual emergence of a vibrant settler culture led to a phase of Australianism which, from the middle to late 19th century challenged inherited British norms, initially in English speech and over time more widely in educational practice. From beginnings in folk literature, Australian communication norms came to be documented and then favoured by those of local or Irish birth, and increasingly by non-British immigrant groups. Such "nationalist" sentiments moved out from folkloric and popular culture to influence wider social practices, though a contest between those seeking to entrench Empire loyalty through language, and those promoting Australian norms, in English usage and more widely, continued for decades and over time became associated with a newfound openness to indigenous and immigrant languages as well.

Eventually, a new cultural force, multiculturalism, emerged as an active language-focused political agitation seeking to make multilingualism and cultural pluralism key dimensions of public policy, especially in education. Originating among second-generation Australian-born children following massive recruitment of new immigrants after the conclusion of World War II, the maximal policy and educational influence of multiculturalism as a social prescription was felt during the late 1970s and through the 1980s. It became the dominant way to think about language learning and use, directly influencing the production of explicit language education policies at state and federal levels, policies in which "foreign" language teaching was discouraged in favour of 
intergenerational maintenance of immigrant and indigenous community languages. This movement transformed primary schools into sites of language study and saw a huge expansion of languages offered.

However, in its turn, multiculturalism was eclipsed by Asianism, the next phase shaping language policy, though with early antecedents from the time of the admission of the UK into the European Common Market in the mid-1970s. Asianism in Australian public policy is often called Asia literacy. This movement spread rapidly and became the dominant force shaping decision making in language education from the late 1980s until today, essentially grounding decisions regarding language choice, curriculum and program design, and target audience on commercial and strategic considerations. In 1994, Asia literacy became overwhelmingly the favoured language policy position, with a narrow selection of four "priority languages": Mandarin Chinese, Indonesian, Japanese, and Korean.

During the mid to late 1990s a new language policy ethos, economism appeared, which has gone hand in hand with Asia literacy. At this time both sides of the traditional political divide in Australia adopted neo-liberal or "economically rationalist" policies that required all language programs to prove their market viability and respond to clear student or employer demand. In addition, a strong focus on global competitive principles for education emerged, especially related to the recruitment of international students to higher education, conceived as a marketable commodity in a global marketplace of education certification and competence. Australian universities - with high schools rapidly following suit - became major providers of English-medium courses and certification, especially to the booming economies of North and Southeast Asia, alongside commercially-minded promotion of the four "priority" Asian foreign languages. Although not always compatible among themselves, given their different priorities and concerns, multiculturalism, Asia literacy and economism, are three overarching public discourses which have left deep imprints on public education, greatly diversifying the languages offered, the target audiences intended for language study, and also curriculum and assessment regimes.

These shifts in policy regarding language provision and the purposes of language study have been accompanied by debates and even disputes regarding the parameters and principles for organising language curricula and evaluation. Controversies arose in the early 1980s regarding the development of the Australian Language Levels (ALL) and the relationship of this school-based framework to the Australian Second Language Proficiency Ratings (ASLPR), previously adopted as the standard means for stating language proficiency in adult learning contexts (Ingram 1984). This wider history of innovation in scale design is essential background to interpreting the fate and fortunes of the CEFR in the Australian setting. The increasing influence of the CEFR on English 
proficiency assessment, a long-established and sophisticated practice in Australia, has been acknowledged as an unavoidable phenomenon in the economism that prevailed in the 1990s, when diverse systems of assessment were permitted to compete in a liberalising education marketplace. An official report on English Language Intensive Courses for Overseas Students (ELICOS) published in 2007 by Elder and O'Loughlin documents this phenomenon of locally generated assessment and curriculum models interacting and competing with imported alternatives. O'Loughlin (2011) reports that Australian universities tend to favour the International English Language Testing System (IELTS). In turn, this close relationship is contributing to the spread of the CEFR, to which IELTS is linked. On the other hand, some researchers condemn the functionalist principles that underpin the CEFR, arguing that such standards tend to impose uniformity on the diversity that is seen as an asset of the current array of proficiency attainment measures and approaches in Australian education, or as a negative instance of globalisation (Scarino 2012), with some repudiating the CEFR as "a mechanism for control of foreign language education throughout every level of the educational system, not only in Europe, but also in Asia, Australasia, South America, and even North America” (McNamara and Elder 2010: 197). In McNamara and Elder argue that the CEFR owes its origins to supranational moves by the Council of Europe to facilitate labour mobility, in line with the economic prescriptions of competitive market liberalisation promoted by the Organization of Economic Cooperation and Development (OECD). Hence, "Frameworks like the CEFR are like the Euro [...]. They make exchanges across boundaries easier, but reduce local variation, and render unintelligible other accounting systems, or sets of cultural values [...]” (McNamara 2011: 504).

\section{A research survey on perceptions of the CEFR in Australian universities}

\subsection{Rationale and design of the project}

Some core concepts promulgated within the discourse and reasoning of the CEFR, especially multiculturalism and multilingualism, are officially valued in Australian educational thinking and promoted by many of the expert critics cited above. It is difficult to assess the direct impact of or attitudes towards the CEFR within the wider higher education community, due to the scant academic literature devoted to its reception in Australia. An extensive Internet search preceding the present study, combining the name of 39 local universities (listed in the site 
australiauniversities.com.au) with the key words CEFR or Common European Framework reveals that only 15 higher education institutions make any mention of the Framework. When cited, the CEFR is linked to learning outcomes, language difficulty levels, or progression sequences in programs and focuses mainly on European languages. Moreover, it often does not appear to be systematically integrated across the operations of the different university departments that mention its adoption. The paucity of research at higher education level is compounded at the school level, where even in European settings there is a dearth of studies conducted among secondary school language teachers (Martyniuk and Noijons 2007), a situation more even more true outside of Europe (Byram et al. 2012a). The upshot of all this is that the general reception of the CEFR in both school and higher education is under-researched, especially with regard to the training of future teachers and the professional development of practising teachers is often predicated on information supplied by recourse to the CEFR.

For all these reasons, the present authors conducted a study in late 2011 to examine both curriculum adaptation and research related to the CEFR in Australian educational settings. As a preliminary activity Normand-Marconnet calibrated learning outcomes from language programs at Monash University with the CEFR's sixlevel scale (A1-C2) as displayed in an interactive website. A short online questionnaire designed using Survey Monkey was included in this website in order to collect feedback from Monash academics and students. Then, in mid-2012, to reach a broader audience, an invitation to participate in the online survey was sent through the Language and Cultures Network for Australian Universities (LCNAU), the key higher education body that brings together tertiary languages providers across Australia, to its 600 affiliated members. The purpose of this survey was to gauge current perceptions of the CEFR across the Australian tertiary sector, and to use this preliminary overview as a starting point for further direct investigation across the sector, with policy makers, administrators and other authorities. To fulfil this purpose, the following research questions were addressed and form the bulk of the analysis in the present article: (i) How do Australian students and academics react to the CEFR? (ii) What do they identify as benefits and problems linked to the implementation of the CEFR in Australia? (iii) How do the views of the respondents align with the prevailing views in the academic literature?

\subsection{Methodology}

Drawing on topics or issues mentioned in the literature on the CEFR, a questionnaire comprising eleven items was designed, including closed and openended questions, as well as statement-type items along a five-point Likert scale. 
Respondents were encouraged to make extended additional comments in sections designed for such open-ended responses. Concerned about the generally low rate of responses received by anonymous online surveys and the large number of unsolicited requests for information academics typically receive via email, we kept the scope and demands of the survey modest and undemanding. By reducing the imposition placed on potential respondents, we hoped to achieve a reasonable response rate and yet still have sufficient depth and range of questions to allow us to focus on salient perceptions about the CEFR in Australian education and begin to fill the void of research in this area. In accordance with university research requirements Human Ethics Certificate Approval was obtained prior to the release of the online questionnaire. Descriptive statistics were collected and analysed through tools embedded in Survey Monkey (i.e. Excel tables). For qualitative data gathered via the comments sections of the questionnaire, NVivo was selected for coding and developing salient themes. NVivo is a Computer-Assisted Qualitative Data Analysis Software (CAQDAS) recognised widely as a powerful and efficient tool for researchers to manage and organise qualitative data (Mackey and Gass 2005).

\section{Students' and academics' perceptions on the CEFR in Australian universities}

\subsection{Main findings from the questionnaire}

The survey was administered during 2012, eliciting a total of 134 responses, 61 from academics and 73 from students, half of whom were enrolled as postgraduates in diploma of education programs.

Overall, nearly 66\% declared that they were familiar with the CEFR, and about $60 \%$ stated they were aware of the Common Reference Levels (from A1 for Basic User to $\mathrm{C} 2$ for Proficient User). As illustrated in Table 1, predictably Table 1: Awareness of the CEFR and the six-level scale.

\begin{tabular}{|c|c|c|c|c|c|c|}
\hline \multirow[t]{2}{*}{ Do you know: } & \multicolumn{2}{|c|}{ Total responses } & \multicolumn{2}{|c|}{ Academics } & \multicolumn{2}{|c|}{ Students } \\
\hline & Yes & No & Yes & No & Yes & No \\
\hline The CEFR (n) & 87 & 46 & 51 & 9 & 36 & 37 \\
\hline$\%$ of total answers & 65.41 & 34.58 & 38.34 & 6.76 & 27.06 & 27.81 \\
\hline The Six Levels Scale (n) & 80 & 54 & 48 & 13 & 32 & 41 \\
\hline$\%$ of total answers & 59.70 & 40.29 & 35.82 & 9.70 & 23.88 & 30.59 \\
\hline
\end{tabular}


perhaps, academic staff are more aware of the CEFR and its six levels, with 99 Yes occurrences against $22 \mathrm{No}$ in answer to the two questions together, whereas the number of No answers was 78 among student respondents.

Respondents were then asked how they had heard about the CEFR and the six-level scale. They were asked to choose from the following options: in class, during language studies; through material used in class; through academic literature; by visiting websites. Table 2 shows that respondents mentioned scientific literature and material used in class as sources of knowledge (respectively 25 and 23 occurrences), while some stated that they had come to know of the CEFR through online website consultation (19 occurrences) and in-class activities (18 occurrences). Furthermore, the additional data provided by the open-ended responses to this question show that opportunities for finding out about the CEFR were the result of collaboration with colleagues (8 occurrences) or had occurred in their previous occupation (7 occurrences) and during professional development sessions (4 occurrences).

Table 2: Opportunities for finding out about the CEFR.

\begin{tabular}{lrr}
\hline Answer options & $\mathbf{n}$ & \% \\
\hline In class, during language studies & 18 & 16 \\
Through material used in language classes & 23 & 20 \\
Through scientific literature & 25 & 22 \\
By visiting the Monash website & 15 & 13 \\
Other & 27 & 23 \\
Total & 116 & 100 \\
Other: & & \\
$\quad$ Previous position & 7 & 26 \\
Through colleagues & 8 & 30 \\
Professional development & 4 & 15 \\
Websites & 4 & 15 \\
Survey & 2 & 7 \\
Other & 2 & 7 \\
Total & 27 & 100 \\
\hline
\end{tabular}

Next respondents were questioned about the extent to which they considered the adoption of the CEFR in their institution to be beneficial. The results appear in Table 3 and show that two-thirds of participants indicated that use of the CEFR within their institution was or could be useful (36\% responded Absolutely, 29\% Somewhat). 
Table 3: Level of agreement on beneficial use of the CEFR in higher education institutions.

\begin{tabular}{|c|c|c|c|c|c|c|}
\hline \multirow[t]{2}{*}{ Answer options } & \multicolumn{2}{|c|}{ Total responses } & \multicolumn{2}{|c|}{ Academics } & \multicolumn{2}{|c|}{ Students } \\
\hline & $\mathbf{n}$ & $\%$ & $\mathrm{n}$ & $\%$ & $\mathbf{n}$ & $\%$ \\
\hline Absolutely & 48 & 36 & 28 & 58 & 20 & 42 \\
\hline Somewhat & 39 & 29 & 16 & 41 & 23 & 59 \\
\hline Not really & 5 & 4 & 5 & 100 & 0 & 0 \\
\hline No at all & 2 & 1 & 2 & 100 & 0 & 0 \\
\hline Don’t know & 41 & 30 & 11 & 27 & 30 & 73 \\
\hline
\end{tabular}

While a large proportion was hesitant (30\% replied with Don't know), it is worth noting that this hesitancy is concentrated among academic staff $(5 \%$ of total answers). In addition, respondents were requested to rate their agreement on perceived benefits available from the CEFR (academic, professional or none) on a Likert-scale from 1 (Strongly agree) to 5 (Strongly disagree). The results show that our participants acknowledged the CEFR as providing both academic and professional benefits (see Table 4). The overall consensus is illustrated by a close rating average for academic (2.09) and professional (2.11) benefits, while the rating average was 3.73 for the No benefit response, although one-third of the respondents stated that they neither agreed nor disagreed.

Table 4: Types of benefits linked to the use of the CEFR in universities.

\begin{tabular}{lccccccr}
\hline Answer option & $\begin{array}{c}\text { Strongly } \\
\text { agree }\end{array}$ & Agree & $\begin{array}{c}\text { Neither agree } \\
\text { nor disagree }\end{array}$ & Disagree & $\begin{array}{c}\text { Strongly } \\
\text { disagree }\end{array}$ & $\begin{array}{r}\text { Total of } \\
\text { responses }\end{array}$ & $\begin{array}{r}\text { Rating } \\
\text { average }\end{array}$ \\
\hline $\begin{array}{l}\text { Academic benefits } \\
\text { (n) }\end{array}$ & 32 & 53 & 39 & 2 & 0 & 126 & 2.09 \\
$\%$ & 25.40 & 42.06 & 30.95 & 1.59 & 0 & 100 & \\
$\begin{array}{l}\text { Professional benefits } \\
\text { (n) }\end{array}$ & 35 & 49 & 36 & 5 & 1 & 126 & 2.11 \\
$\%$ & 27.78 & 38.89 & 28.57 & 3.97 & 0.79 & 100 & \\
$\begin{array}{l}\text { No benefits } \\
\text { (n) }\end{array}$ & 3 & 7 & 34 & 32 & 29 & 105 & 3.73 \\
$\%$ & 2.86 & 6.67 & 32.38 & 30.48 & 27.62 & 100 & \\
\hline
\end{tabular}

To explore positive impacts of the CEFR on institutions, a series of five additional Likert-scale items was included. As shown in Table 5, respondents were asked to comment on the following benefits of the CEFR extracted from the literature: "the CEFR is now implemented not only in Europe but all around the world" (item 1); "the can do descriptors are easy to use to map language levels" (item 2); "the CEFR 
Table 5: Positive perceptions of the CEFR.

\begin{tabular}{|c|c|c|c|c|c|c|c|}
\hline Benefits & $\begin{array}{r}\text { Strongly } \\
\text { agree }\end{array}$ & Agree & $\begin{array}{r}\text { Neither } \\
\text { agree nor } \\
\text { disagree }\end{array}$ & Disagree & $\begin{array}{l}\text { Strongly } \\
\text { disagree }\end{array}$ & $\begin{array}{r}\text { Total of } \\
\text { responses }\end{array}$ & $\begin{array}{r}\text { Rating } \\
\text { average }\end{array}$ \\
\hline \multicolumn{8}{|c|}{$\begin{array}{l}\text { The CEFR is used } \\
\text { around the world }\end{array}$} \\
\hline (n) & 36 & 46 & 34 & 11 & 1 & 130 & 2.18 \\
\hline$\%$ & 27.69 & 35.38 & 26.15 & 8.46 & 0.77 & 100 & \\
\hline \multicolumn{8}{|c|}{$\begin{array}{l}\text { Can do are easy } \\
\text { to use }\end{array}$} \\
\hline (n) & 34 & 32 & 37 & 4 & 0 & 127 & 2.09 \\
\hline$\%$ & 26.77 & 40.94 & 29.13 & 3.15 & 0 & 100 & \\
\hline \multicolumn{8}{|c|}{$\begin{array}{l}\text { The CEFR is an } \\
\text { international } \\
\text { standard }\end{array}$} \\
\hline (n) & 45 & 49 & 28 & 4 & 1 & 127 & 1.95 \\
\hline$\%$ & 35.43 & 38.58 & 22.05 & 3.15 & 0.79 & 100 & \\
\hline \multicolumn{8}{|c|}{$\begin{array}{l}\text { It promotes better } \\
\text { curriculum design }\end{array}$} \\
\hline (n) & 38 & 51 & 30 & 6 & 2 & 127 & 2.08 \\
\hline$\%$ & 29.92 & 40.16 & 23.62 & 4.72 & 1.57 & 100 & \\
\hline \multicolumn{8}{|c|}{$\begin{array}{l}\text { assessment } \\
\text { aligned with } \\
\text { proficiency level }\end{array}$} \\
\hline (n) & 31 & 62 & 27 & 7 & 0 & 127 & 2.08 \\
\hline$\%$ & 24.41 & 48.82 & 21.26 & 5.51 & 0 & 100 & \\
\hline
\end{tabular}

evaluates outcomes against an international standard" (item3); "it promotes better curriculum design across languages" (item 4); "this framework provides ways to align assessment with proficiency level" (item 5). According to the rating average and the grouping of Strongly agree/Agree categories in percentages, our participants were more likely to agree with the claim that incorporating the CEFR would be particularly useful as it evaluates outcomes against an international standard (rating average of 1.95 and $74 \%$ of positive answers). The claim that the CEFR provides a means of aligning assessment with proficiency level and promotes better curriculum design across languages was also well supported (rating average of 2.08 with respectively $73 \%$ and $70 \%$ of positive answers). To a lesser degree, the claim that the CEFR is beneficial is linked to the ease of using can do descriptors to map language levels (rating average of 2.09 and $68 \%$ of positive answers), and to the CEFR's implementation all around the world (rating average of 2.18 and $64 \%$ of positive answers). 
Table 6: Negative perceptions of the CEFR.

\begin{tabular}{|c|c|c|c|c|c|c|c|}
\hline Challenges & $\begin{array}{r}\text { Strongly } \\
\text { agree }\end{array}$ & Agree & $\begin{array}{r}\text { Neither } \\
\text { agree nor } \\
\text { disagree }\end{array}$ & Disagree & $\begin{array}{l}\text { Strongly } \\
\text { disagree }\end{array}$ & $\begin{array}{r}\text { Total of } \\
\text { responses }\end{array}$ & $\begin{array}{r}\text { Rating } \\
\text { average }\end{array}$ \\
\hline \multicolumn{8}{|c|}{ The CEFR is not well } \\
\hline \multicolumn{8}{|c|}{ known in Australia } \\
\hline (n) & 18 & 34 & 43 & 25 & 5 & 125 & 2.72 \\
\hline$\%$ & 14.40 & 27.20 & 34.40 & 20.00 & 4.00 & 100 & \\
\hline \multicolumn{8}{|c|}{ The CEFR is not adapted } \\
\hline (n) & 10 & 23 & 50 & 32 & 10 & 125 & 3.07 \\
\hline$\%$ & 8.00 & 18.40 & 40.00 & 25.60 & 8.00 & 100 & \\
\hline \multicolumn{8}{|c|}{ The CEFR is complicated } \\
\hline (n) & 0 & 7 & 62 & 35 & 19 & 123 & 3.54 \\
\hline$\%$ & 0.00 & 5.69 & 50.41 & 28.46 & 15.45 & 100 & \\
\hline \multicolumn{8}{|c|}{ It gives an unclear picture } \\
\hline (n) & 4 & 16 & 42 & 46 & 16 & 124 & 3.44 \\
\hline$\%$ & 3.23 & 12.90 & 33.87 & 37.10 & 12.90 & 100 & \\
\hline \multicolumn{8}{|c|}{$\begin{array}{l}\text { Standardisation and } \\
\text { harmonisation prevent } \\
\text { flexibility and diversity }\end{array}$} \\
\hline (n) & 8 & 25 & 40 & 36 & 16 & 125 & 3.22 \\
\hline$\%$ & 6.40 & 20.00 & 32.00 & 28.80 & 12.80 & 100 & \\
\hline
\end{tabular}

Mirroring this section on positive claims made for the adoption of the CEFR in a given institution, the subsequent question sought to clarify rejection or repudiation of the CEFR by proposing five reasons that would make its adoption irrelevant, impractical or harmful in an Australian university (see Table 6). Overall, $42 \%$ of respondents declared that negative perception of the CEFR and its six-level scale in Australia was largely due to limited awareness of CEFR (rating average of 2.72 for item 1). Furthermore, the reasons given for its limited uptake were not due to complications inherent in the CEFR (rating average of 3.54 for item 3) or its failure to supply a clear picture of language proficiency (rating average of 3.44 for item 4). Almost half (42\%) also disagreed with the suggestion that standardisation and harmonisation involve less flexibility and reduced diversity in language programming (rating average of 3.22 for item 5). There seemed to be a high level of indecision regarding the claim that the CEFR is not well integrated into or adapted to the Australian setting (rating average of 3.07 for item 2, and $40 \%$ of Neither agree nor disagree responses). 
Finally, in the two last questions, $74 \%$ of respondents agreed with the idea that their institution should not only promote use of the CEFR, but should organize training sessions prior to its implementation. It is noteworthy that the strongest opposition to these statements came from academics (80\% of negative responses), whereas the need for training was mostly affirmed by students $(60 \%$ of positive responses).

\subsection{Additional insights provided by respondents' comments}

The principles of content analysis were applied to additional data collected from the open-ended sections in the questionnaire. An identification code was allocated to each respondent's dataset (from R1 to R134) and students were distinguished from staff. Significant segments were identified by reading the comments repeatedly, then coded using NVivo, and grouped into three main categories: neutral opinions, pros and cons.

The dataset comprised 67 additional comments: 22 quotes were assigned to a No idea category, 14 to the Cons category, and 31 to the Pros category. These three categories were then divided into subcategories according to the different clusters that emerged during the coding process. Representative quotes were selected to illustrate the main findings from the corpus.

\subsubsection{Neutral perceptions}

In the first of these three categories, the majority of comments were simple quotes such as "I don't know". Nevertheless, some elaborated on this, stating, for example, "[...] I don't have personal knowledge of whether the CEFR is well known in Australia or not" (R71 - staff). Others added that they would like more information, such as student R65: "Have never heard about this, perhaps it would be good to promote/explain a bit more about what it is in class or via email, etc.”

\subsubsection{Negative perceptions}

Although limited in number, the comments assigned to the Cons category, provided by 14 respondents (13 academics and one student), nevertheless cover a similar range of criticisms to the one we encounter in the academic literature. 
Four clusters were identified: the claimed inapplicability of the CEFR in a non-European context; the limitations of the CEFR in terms of assessment and curriculum design; the risks inherent in standardised benchmarking; and finally, the relevance of the CEFR compared to other existing standards. Not surprisingly, the main source of doubt and concern from six of our respondents focused on the question of how applicable the CEFR and the six-level scale are to non-European languages, especially Asian languages, for example: "I doubt if it can measure script-based Asian language proficiency correctly” (R75/staff); "There is an assumption that CEFR suits all languages - it is totally impractical for non-European languages and this needs to be more widely acknowledged and recognised" (R84/staff).

Others pointed out limitations of the CEFR in terms of assessment or curriculum design, sometimes quite vigorously: "[Students] can perceive by self-assessing how close or how far they may be but it is NOT a reliable measure in ANY WAY" (R86/ staff, capitals in original). Another academic explained the risks linked to using the CEFR as a benchmarking tool as follows: "One major problem in Australian unis [universities] is the ongoing reduction in teaching hours per subject at each level (1st/2nd/3 $3^{\text {rd }}$ year). As the decisions to reduce hours are based solely on economic bases, and not on proficiency/outcomes, the CEFR could serve as a means to prove the teaching/learning case for a minimum of contact hours" (R128/staff).

Finally, the relevance of the CEFR to Australian conditions compared to other available international standards was also questioned: "It is unclear to me why CEFR has been chosen among all systems to be the standard. For example, why haven't we chosen the system used by the U.S. State Department or other? These are equally as recognisable outside of Europe" (R99/staff).

\subsubsection{Positive perceptions}

The pros category is composed of 31 comments divided into the following five sub-categories: the acknowledgement of beneficial implementation of the CEFR in their institution; the positive reception of the CEFR in general; the positive impact of the CEFR on curriculum and assessment; its positive impact in additional fields of implementation; and the necessary adjustments in terms of professional development. In the first sub-category, respondents reported successful implementation of the CEFR in their institution: "We have used the CEFR in the Spanish Program at [our university] for more than five years now, with great success" (R116/staff), and spoke of it enthusiastically: "I am a fan of the European Reference Framework and in this day and age of globalisation, the more 'international' education is, the better!” (R97/staff). 
In the second sub-category, we grouped together positive comments on the CEFR such as: "self-explanatory" (R110/staff); "incorporates intercultural and socio-cultural features" (R119/staff); or "promotes academic mobility" (R120/ staff and R130/staff). We also included the positive reaction to the CEFR in relation to curriculum design and assessment by two students, as follows: "I think it would be a good thing to know if you're a (for example) level B2 in reading and listening, but only a B1 in writing and speaking. Perhaps then a grade of Credit would make a bit more sense (rather than thinking you are just mediocre overall)" (R44/student); and "Best part about [this] system is that it provides clear goals/guidelines that must be met by students and set by assessors as to reach the next level" (R70/student).

Other comments focused on the potential extension across the sector for international students (R81/staff), and even its role in promoting cohesion between secondary and tertiary levels: "I'd like to think we could adapt this to secondary level and promote a cohesive approach across Australia" (R102/staff).

Finally, some participants believed there would be a potential positive impact of the CEFR on their institution, provided that a review of the programs (R107/staff) and some professional development activities were included in the implementation of the Framework and the six-level scale: "I would be very interested in running some PD for teachers in how to implement the framework reference and combine this with state and national descriptors" (R81/staff).

\section{A balanced perception of the CEFR in Australian universities: Discussion and implications}

Despite limitations due to the relatively small size and preliminary nature of the survey, this article represents an instalment in understanding this kind of educational innovation and a first indication of the range and depth of views and reactions to the issues that have arisen and will predictably emerge from the ongoing press to adapt the CEFR for use in Australian settings. This is also valuable because of the generally low penetration of the CEFR within the Australian higher education scene, in which the views of students and academics in the language education enterprise are critical to comprehending likely future developments. Generalisation to the entire higher education sector would undeniably require further investigation to collect additional data (through interviews and focus groups, for example) and allow triangulation.

In summary, the results of our survey and literature review provide two main outcomes. The first is to note a disparity between the opinions on the CEFR 
expressed by our respondents, and its largely critical reception within the Australian applied linguistics, language testing and SLA academic literatures. The second broad outcome is the finding of an overall congruence regarding the merits of the CEFR and the challenges its implementation poses, between our data, limited and preliminary though it is, and general acceptance of CEFR within the wider academic literature.

From both the statistical and qualitative data, it can be argued that our respondents seem to be less concerned by the application of learning and curriculum standards than some local researchers and applied linguists. Due to their position, the latter are certainly better aware of theoretical problems linked to standards and frameworks such as the CEFR. Perhaps surprisingly, in light of a key objection from expert scholars, the majority of our respondents believed that adoption of the CEFR and its six-level scale in their institution would be beneficial precisely because these allow learning outcomes to be aligned with an international benchmark. Likewise, 42\% disagree that there is a negative relationship between standardising the measurement of learning outcomes and retaining flexibility and diversity in language programming. Only 26\% agree and 32\% are not sure on this crucial criticism levied against use of the CEFR. Though with a lower rate of agreement (26\%) but the highest proportion of answers in the Neither agree nor disagree category (40\%), they also appear disinclined to reject the CEFR on the basis that it is not adapted to Australian educational settings.

In brief, and in keeping with the moves noted above depicting the main discourses in historical language planning in Australia, respondents are not particularly protective, as Australianist reasoning would predict, of national education systems, i.e. insisting that the country should have its own distinctive assessment systems designed for its particular needs. Instead they appear more attuned to the multiculturalism and economism discourses, in that decisions about language offerings might well be decided according to criteria of relative efficiency and pluralism.

It should be kept in mind that criticism of the CEFR and claims that it has been imposed from outside have also surfaced in some European settings, such as Poland, where a national education evaluation tradition appears to conflict with the principles inherent in the CEFR (Komorowska 2012). Even in Germany, similar negative perceptions, and specifically claims of a danger of "Macdonaldisation" in foreign language research triggered by the generalisation of efficiency and control measures promoted by the CEFR, has been raised (Hu 2012). It appears therefore that the different ways in which different societies' adoption of the CEFR has been rejected, delayed or otherwise minimised had been due to two kinds of reasoning, national protection and pluralism promotion. 
The first of these, national protection, is somewhat negative in character, while pluralism promotion aims to be positive in outlook. As we have seen both of these kinds of reasoning occur even in major western European contexts. We should not be surprised therefore that Australia, with its longstanding independent traditions of scientifically based language proficiency research, and its unique educational characteristics, would also give rise to robust discussion and critique of external language assessment regimes. However, it is also clear from our evidence that respondents are not primarily worried about any normative characteristics within CEFR. Unlike the theoretical arguments raised by researchers who have critiqued the Framework as a functionalist, instrumental adjunct of rampant globalisation, the main perceptions among language educators and students in higher education appear to be motivated by quite pragmatic considerations.

In any case, perceived challenges and benefits associated with implementation of the CEFR and the six-level scale in Australian universities echo the findings of previous studies. Specifically, some respondents share with their peers around the world doubts and fears regarding the adoption of an external or foreign framework to be used in a "very different scenario". This was the finding reported by de Mejía in Columbia, who argued that "international organisations are driving definition of local standards that are not in concordance with the local socio-economic context" and "expectations of B1 level as a goal for all schools leavers are unrealistic” (de Mejía 2012: 153).

These practices appear to us as a misuse or at least an inappropriate use of the CEFR and regrettably appear to be increasing, as described by Castellotti: "We can see this in many places, in form of 'blind' application of the scales, and of excessive standardisation where there is no reflection on the modes of assessment and the necessary relative and situated nature of the competences in question" (Castellotti 2012: 50). This identification of inappropriate application is close to what the Australian critics cited earlier predicted would occur. Closely linked to perceived misuse is a more common feeling that the CEFR, obviously initially designed in the European context and principally with European languages in mind, cannot be adapted for use with Asian languages. This concern was one of the most strongly encountered in our dataset, a clear resonance of the Asianist discourse in Australian language education which remains vibrant all across the country. It needs to be kept in mind that Asian language education has been a prominent feature of public discourse about the economic and strategic future of the country for at least four decades, with major consequences for national identity as much as for educational practice.

In light of this, it is interesting and relevant to consider the recent history of adaptation of the CEFR in key Asian settings and specifically in relation to the 
teaching of Chinese and Japanese as foreign languages. The Framework has been fully translated into both languages, with a focus on the English curriculum in China (Rong 2010), and through a contextualisation of can do statements in the CEFR-Japan project (O’Dwyer and Nagai 2011). The translated CEFR is used as a basis for the project to develop a Common Framework for Chinese (Bellassen and Zhang 2008), and the Japan Foundation has developed its own Standards for Japanese Education published in 2010. These Standards, which are derived from the CEFR, are not only officially in use for Japanese as a foreign language, but are also intended to be adapted for the teaching of Chinese and Korean in Japan under the form of Learning Targets (Sugitani and Tomita 2012).

Our respondents also expressed doubts about how reliable any benchmarked standards of proficiency measurement could be, doubts which are in line with academic criticism illustrating weaknesses of CEFR descriptors (Fulcher 2004; Alderson et al. 2006; Hulstijn 2007). Such criticisms are not unfounded. One concrete illustration of such shortcomings is found in the project to align the General Proficiency Test of English used in Taiwan with the CEFR, a process which revealed, among other technical problems, a prejudicial lack of precision in can do statements for evaluating learners' performance ( $\mathrm{Wu}$ and $\mathrm{Wu}$ 2007). On the other hand, the survey conducted by Glover in Turkey, with 62 first-year students training to become teachers of English in that country, demonstrated positive outcomes of assessment and self-assessment activities based on the CEFR. Glover's findings suggest that the CEFR "helped to raise these students' awareness of their speaking skills by providing them with a language they could use to describe their abilities" (Glover 2011: 131). Furthermore, the drawbacks of what McKay and Brindley (2007) described as commodification of education needs are also noticeable in our survey, especially the comments which emphasized the risks of equating proficiency with the number of hours taught.

Finally, the quote we cited above which questions the selection of the CEFR in preference to proficiency assessment systems used by the State Department in the United States is a kind of negative perception also reported by Byrnes (2012) in the United States, where the CEFR is in competition with the Standards for Foreign Language Learning.

Overall, our data illustrate a generally positive and mostly pragmatic acceptance of the prospect of greater use of CEFR, counterbalanced by lack of familiarity with its key design features and criticisms marshalled against its use. It seems that opportunities for students and academics to become familiar with the CEFR and the six-level scale are mostly through informal professional networks, or by word-of-mouth recommendation, rather than by any systematic or formally organised, institution-based promotion. It appears significant that respondents identified unfamiliarity, rather than any key deficiency in design or 
conceptualisation, or any negative impact in usage, as one of the main explanations for its limited penetration in higher education language teaching. This suggests that the potential for expansion exists through promotion, supported by the responses which stated that provision of training sessions managed prior to implementation of the CEFR would be welcomed. It is interesting to note that the absence of systemic training in the use of the CEFR and education about its underlying theories of proficiency is a common lament and research finding in many parts of the world in the literature on its implementation. According to Faez et al. (2012), who examined teacher perceptions of the CEFR's “actionoriented approach" in French as Second Language classes among elementary and secondary school teachers in Ontario, Canada, the main obstacle to implementation of the CEFR was a lack of basic understanding of the Framework and its operation. The authors concluded that it was mostly this failure to provide targeted professional development which impeded greater use of the CEFR in Ontario schools. In Colombia, the Ministry of National Education stated in 2005 that the CEFR levels and skill descriptions would strengthen and focus the teaching and learning of English within the country (López Mendoza and Janssen 2011). As reported by de Mejía (2012), the adoption of the CEFR as a guiding document in the National Bilingual Program has provoked resistance and dissatisfaction among teachers who considered that the bilingual policy was imposed on them from above, overwhelming them with additional work required for its implementation. A similar phenomenon of resistance against top-down imposition occurred in Japan, "where good intention may result in vain if teachers are not sharing basic philosophy and ideas promoted by the CEFR” (O’Dwyer and Nagai 2011: 146).

Although imposition of the CEFR is extremely unlikely in Australia, the expanding influence of the Framework globally presents dilemmas for teachers and policy makers alike, and remains a pertinent question in language policy terms due to the increasing globalisation of educational policy and especially the pressure for the generation of internationally comparative information across all sectors of education. Although institutional autonomy is highly prized, governments stimulate common practices by privileging funding schemes and incentives provided to improve ranking against international benchmarks. These forces are well beyond the control of language educators and researchers. The present research leads us to support the claim by de Mejía that "adapting rather than adopting is very much part of the on-going debate both in Colombia and other parts of the world" (2012: 156). We hope this research is seen as a contribution to debate about the limits and problems of policy borrowing, about the virtues and dilemmas of a plurality of approaches and methods in assessment of outcomes of language education, and specifically as a documentation of the complex 
processes involved in the spread of the CEFR, with the semi-autonomous views and positions of language academics, specialist researchers, students and policymakers, all perceiving and responding to its availability in different ways. Specifically we hope to stimulate discussion about the role, limits and potential of the CEFR in the context of language learning and teaching in Australian higher education.

The environment of language teaching internationally is rapidly developing, and the increasing visibility of the CEFR in recent years is a key indicator of one of the ways such change has occurred, i.e., though adoption and adaptation, localisation and importation, of common instruments and measures to permit comparative global conversations. The assumptions and underlying design principles of the CEFR, and other Frameworks for describing, measuring or conceiving of language acquisition and growth, are increasingly attractive to policy makers and administrators, but also to students and lecturers. A lively critical debate about both administrative components and educational dimensions of assessment regimes, based on research into the promise and limitations, attractiveness and potentially disrupting effects, will benefit the field. A better knowledge of benefits and challenges related to the adoption of the CEFR is needed so that its likely expansion in Australian universities can be supported by targeted professional development for language practitioners, to prevent misuse and inappropriate use, and to bolster the claim that a range of measures and approaches is likely to be preferable to reliance on a single uniform approach.

\section{Conclusion}

In the context of Australian LP history and the provision of languages, what are the prospects for adoption, modification, or outright rejection of the CEFR? To better evaluate these eventualities, we examined data showing the reactions and views of those most concerned, that is, academics and students (among whom are future and currently serving language teachers). The literature on policy borrowing suggests that actors other than teachers and researchers, even beyond local administration and policy makers, are involved in determining how and to what extent external innovations are transferred and taken up in any given context. The current lack of familiarity with the CEFR is a weak barrier that is likely to be challenged by pressure from macro-level LP, as evidenced by the strong pressure towards substantial internationally comparable assessments. There is a proliferation of these, the most prominent being the Programme for 
International Student Assessment (PISA), Trends in International Mathematics and Science Study (TIMSS), the Programme for the International Assessment of Adult Competencies (PIAAC), the IALS (International Adult Literacy Survey) and a variety of ways in which universities themselves are ranked against global counterparts. In one sense the CEFR is part of this wider move towards globally standardised instruments of measurement and reporting.

Another possible avenue for deeper penetration by the CEFR into Australian higher education appears to be from bottom-up pressure, either from second language teachers in schools, or from higher education language students. Here too the increasing popularity of the International Baccalaureate (IB) suggests the emergence of interconnected systems of education practice that could pave the way for the CEFR to be incorporated into the educational measurement procedures of an increased number of Australian institutions.

These are two potential sources that could generate wider adoption of the CEFR. Our modest research suggests that deeper conversations between practitioners, researchers and students are needed to prepare the ground for local experimentation, adaptation and mixing of a plurality of teaching and assessment tools to gain the benefits of comparability without sacrificing local autonomy.

\section{References}

Alderson, J. Charles, Neus Figueras, Henk Kuijper, Guenter Nold, Sauli Takala \& Claire Tardieu. 2006. Analysing tests of reading and listening in relation to the Common European Framework of Reference: The experience of the Dutch CEFR construct project. Language Assessment Quarterly 3(1). 3-30. doi:10.1207/s15434311laq0301_2.

Bellassen, Joël \& Li Zhang. 2008. The enlightenment and the impetus of the new approach of the Common European Framework of Reference for Language on the Chinese language teaching. Chinese Teaching in the World 3. 58-73.

Byram, Michael \& Lynne Parmenter (eds.). 2012a. The Common European Framework of Reference: The globalisation of language education policy. Bristol: Multilingual Matters.

Byram, Michael \& Lynne Parmenter. 2012b. Introduction. In Michael Byram \& Lynne Parmenter (eds.), The Common European Framework of Reference: The globalisation of language education policy, 1-11. Bristol: Multilingual Matters.

Byrnes, Heidi. 2012. Academic perspectives from the USA. In Michael Byram \& Lynne Parmenter (eds.), The Common European Framework of Reference: The globalisation of language education policy, 169-181. Bristol: Multilingual Matters.

Castellotti, Véronique. 2012. Academic perspectives from France. In Michael Byram \& Lynne Parmenter (eds.), The Common European Framework of Reference: The globalisation of language education policy, 45-52. Bristol: Multilingual Matters. 
Coste, D. 2007. Contextualising uses of the Common European Framework of Reference for Languages. Paper presented at the Report of the Intergovernmental Forum The Common European Framework of Reference for Languages (CEFR) and the development of language policies: challenges and responsibilities. Council of Europe. http://www.coe.int/t/dg4/ linguistic/Source/SourceForum07/ForumFeb07_\%20Report_EN.doc (accessed 18 June 2015).

Council of Europe. 2001. Common European Framework of Reference for Languages: Learning, teaching, assessment. Cambridge: Cambridge University Press.

Council of Europe. 2007. The Common European Framework of Reference for Languages (CEFR) and the development of language policies: Challenges and responsibilities. Report on an Intergovernmental Language Policy Forum. Strasbourg: Council of Europe. http://www.coe. int/t/dg4/linguistic/conference_bis_en.asp\#P40_1517 (accessed 10 June 2015).

Davidson, Fred \& Glenn Fulcher. 2007. The Common European Framework of Reference (CEFR) and the design of language tests: A matter of effect. Language Teaching 40(3). 231-241.

Despagne, Colette \& John Roby Grossi. 2011. Implementation of the CEFR in the Mexican context. Synergies Europe 6. 65-74.

Elder, Catherine \& Kieran O'Loughlin. 2007. ELICOS language levels feasibility study: Final report. Canberra: Department of Education, Science and Training.

Faez, Farahnaz, Suzanne Majhanovich, Shelley Taylor, Maureen Smith \& Kelly Crowley. 2012. The power of "can do" statements: Teachers' perceptions of CEFR-informed instruction in French as a Second Language classrooms in Ontario. Canadian Journal of Applied Linguistics/Revue canadienne de linguistique appliquée 14(2). 1-19.

Finch, Andrew E. 2009. Europass and the CEFR: Implications for language teaching in Korea. English Language and Literature Teaching 15(2). 71-92.

Fleming, Mike. 2006. The use and mis-use of competence frameworks and statements with particular attention to describing achievements in literature. https://www.coe.int/t/dg4/ linguistic/Source/Fleming-paper.doc (accessed 19 September 2014).

Fulcher, Glenn. 2004. Are Europe's tests being built on an "unsafe" framework. The Guardian Weekly 18.

Glover, Philip. 2011. Using CEFR level descriptors to raise university students' awareness of their speaking skills. Language Awareness 20(2). 121-133.

Hu, Adelheid. 2012. Academic perspectives from Germany. In Michael Byram \& Lynne Parmenter (eds.), The Common European Framework of Reference: The globalisation of language education policy, 66-75. Bristol: Multilingual Matters.

Hulstijn, Jan H. 2007. The shaky ground beneath the CEFR: Quantitative and qualitative dimensions of language proficiency. The Modern Language Journal 91(4). 663-667. doi:10.2307/4626094.

Ingram, David E. 1984. Report on the formal trialling of the Australian second language proficiency ratings (ASLPR). Canberra: Australian Government Publishing Service.

Jones, Neil \& Nick Saville. 2009. European language policy: Assessment, learning and the CEFR. Annual Review of Applied Linguistics 29(1). 51-63.

Komorowska, Hanna. 2012. Academic perspectives from Poland. In Michael Byram \& Lynne Parmenter (eds.), The Common European Framework of Reference: The globalisation of language education policy, 104-113. Bristol: Multilingual Matters.

Krumm, Hans-Jürgen. 2007. Profiles instead of levels: The CEFR and its (ab)uses in the context of migration. The Modern Language Journal 91(4). 667-669. doi:10.2307/4626095. 
Little, David. 2007. The Common European Framework of Reference for Languages: Perspectives on the making of supranational language education policy. The Modern Language Journal 91(4). 645-655. doi:10.2307/4626091.

Little, David, Francis Goullier \& Gareth Hughes. 2011. The European Language Portfolio: The story so far (1991-2011). Strasbourg: Council of Europe. http://www.coe.int/t/dg4/educa tion/elp/elp-reg/Source/Publications/ELP_StorySoFar_July2011_Final_EN.pdf (accessed 3 July 2015).

Lo Bianco, Joseph. 2004. A site for debate, negotiation and contest of national identity: Language policy in Australia. Strasbourg: Council of Europe. http://www.coe.int/t/dg4/ linguistic/Source/LoBiancoEn.pdf (accessed 9 June 2015).

Lockwood, Jane. 2012. Are we getting the right people for the job? A study of English language recruitment assessment practices in the business processing outsourcing sector: India and the Philippines. Journal of Business Communication 49(2). 107-127.

López Mendoza, Alexis Augusto \& Gerriet Janssen. 2011. Estudio de validación de la prueba de inglés de ECAES en Colombia. Lenguaje 38(2). 423-448.

Mackey, Alison \& Susan M. Gass. 2005. Second language research: Methodology and design. Mahwah, NJ: Lawrence Erlbaum.

McBeath, Neil. 2011. The Common European Framework of Reference for Language: Learning, teaching, assessment. Arab World English Journal 2(1). 186-213.

McKay, Penny \& Geoff Brindley. 2007. Educational reform and ESL assessment in Australia: New roles and new tensions. Language Assessment Quarterly 4(1). 69-84.

McNamara, Tim. 2011. Managing learning: Authority and language assessment. Language Teaching 44(4). 500-515.

McNamara, Tim \& Catherine Elder. 2010. Beyond scales. In Anthony J. Liddicoat \& Angela Scarino (eds.), Languages in Australian education: Problems, prospects and future directions. 193-201. Newcastle upon Tyne: Cambridge Scholars Publishing.

Martyniuk, Waldemar \& José Noijons. 2007. Executive summary of results of a survey on the use of the CEFR at national level in the Council of Europe member states. Strasbourg: Council of Europe.

Mejía, Anne-Marie de. 2012. Academic perspectives from Colombia. In Michael Byram \& Lynne Parmenter (eds.), The Common European Framework of Reference: The globalisation of language education policy, 149-157. Bristol: Multilingual Matters.

Noriyuki, Nishiyama. 2009. L'impact du Cadre européen commun de référence pour les langues dans l'Asie du Nord-Est: pour une meilleure contextualisation du CECR. 54 -70.

Normand-Marconnet, Nadine. 2013. Pedagogical challenges of self-assessment in an Islamic context: A case of Iranian learning French students. International Journal of Pedagogies \& Learning 7(3). 200-210.

North, Brian. 2014. Putting the Common European Framework of Reference to good use. Language Teaching 47(2). 228-249. doi:10.1017/S0261444811000206.

O’Dwyer, Fergus \& Noriko Nagai. 2011. The actual and potential impacts of the CEFR on language education in Japan. Synergies Europe 6. 141-152.

O'Loughlin, Kieran. 2011. The interpretation and use of proficiency test scores in university selection: How valid and ethical are they? Language Assessment Quarterly 8(2). 146-160.

Porto, Melina. 2012. Academic perspectives from Argentina. In Michael Byram \& Lynne Parmenter (eds.), The Common European Framework of Reference: The globalisation of language education policy, 192-138. Bristol: Multilingual Matters. 
Rong, Fu. 2010. Une contribution à la diffusion en Chine des notions de didactique des langues: le cas de l'expérience de traduction du Cadre européen commun de référence du français en chinois. Synergies Chine 5. 171-177.

Scarino, Angela. 2012. A rationale for acknowledging the diversity of learner achievements in learning particular languages in school education in Australia. Australian Review of Applied Linguistics 35(3). 231-250.

Sugitani, Masako \& Yuichi Tomita. 2012. Perspectives from Japan. In Michael Byram \& Lynne Parmenter (eds.), The Common European Framework of Reference: The globalisation of language education policy, 198-211. Bristol: Multilingual Matters.

Suzuki, Elli \& Yumiko Togashi. 2013. Le «JF Standard», copie conforme du CECRL?. In Joël Bellassen, Héba Medhat-Lecocq \& Louise Ouvrard (eds.), Ecritures, politiques linguistiques et didactique des langues, 77-91. Paris: Editions des Archives Contemporaines.

Trim, John L. M. 2012. The Common European Framework of Reference for Languages and its background: A case study of cultural politics and educational influences. In Michael Byram \& Lynne Parmenter (eds.), The Common European Framework of Reference: The globalisation of language education policy, 4-34. Bristol: Multilingual Matters.

Üstünlüoğlu, Evrim, Kısmet Funda Akgül Zazaoğlu, Michelle N. Keskin, Beril Sarayköylü \& Gülfem Akdoğan. 2012. Developing a CEF based curriculum: A case study. International Journal of Instruction 5(1). 115-128.

Vandergrift, Larry. 2006. Nouvelles perspectives canadiennes. Proposition d'un cadre commun de référence pour les langues pour le Canada. Ottawa: Patrimoine Canadien.

Weir, Cyril J. 2005. Limitations of the Common European Framework for developing comparable examinations and tests. Language Testing 22(3). 281-300.

Wernicke, Meike \& Monique Bournot-Trites. 2012. Introducing the CEFR in BC: Questions and challenges. Canadian Journal of Applied Linguistics/Revue canadienne de linguistique appliquée 14(2). 106-128.

Wu, Jessica. 2012. Policy perspectives from Taiwan. In Michael Byram \& Lynne Parmenter (eds.), The Common European Framework of Reference: The globalisation of language education policy, 213-223. Bristol: Multilingual Matters.

Wu, Jessica R. W. \& Rachel Y. F. Wu. 2007. Using the CEFR in Taiwan: The perspective of a local examination board. The Language Training and Testing Center Annual Report 56. Taipei: National Taiwan University.

\section{Appendix: Questionnaire for students and staff}

1. Are you a/an: undergraduate student / honours student / postgraduate student / sessional academic staff / permanent academic staff

2. Have you visited the new Monash website on "CEFR in Australia, an international language framework"?

Yes/No

3. Do you know what the Common European Framework of Reference for Languages is?

Yes/No 
4. Do you know what the Common Reference Levels are?

Yes/No

5. If so, how have you heard about it?

In class, during previous language studies

Through material used in language classes

Through scientific literature

By visiting the Monash website

Other (please specify)

6. Do you think that the adaptation of CEFR to language programs in your institution could be helpful?

Absolutely

Somewhat

Not really

Not at all

Don't know

7. You think that the use of Common Reference Levels will give you:

(Please grade following proposal as follows: $1=$ strongly agree; 2 = agree; $3=$ no opinion; 4 = disagree; $5=$ strongly disagree)

Academic benefits / Professional benefits / No benefits

8. You think that the adaptation of CEFR to language programs in your institution is/could be helpful because ...

(Please grade following proposal as follows: $1=$ strongly agree; 2 = agree; $3=$ no opinion; 4 = disagree; $5=$ strongly disagree)

The CEFR is now implemented not only in Europe but all around the world The "can do" descriptors are easy to use to map language levels

It evaluates outcomes against an international standard

It promotes better curriculum design across languages

It provides ways to align assessment with proficiency level

8.a Are there other benefits that are not listed above? (Please specify)

9. You think that the adaptation of CEFR to language programs in your institution is/could be not helpful because ...

(Please grade following proposal as follows: $1=$ strongly agree; 2 = agree; $3=$ no opinion; 4 = disagree; $5=$ strongly disagree)

The CEFR and its 6 Reference Levels are not well known in Australia

This framework is not adapted to the Australian context

The use of this framework is too complicated

The 6 Reference Levels do not give a clear picture of language proficiency 
Standardisation and harmonisation mean less flexibility and less diversity in language programs

9. a Are there other negative aspects that are not listed above? (Please specify)

10. Do you think that your institution should promote the use of CEFR and Reference Levels?

Absolutely / Somewhat / Not really / Not at all / Don't know

11. Do you think that your institution should provide training sessions to better understand the use of the CEFR and Common Reference Levels?

Absolutely / Somewhat / Not really / Not at all / Don't know

12. Any other comments:

\section{Bionotes}

\section{Nadine Normand-Marconnet}

Dr Nadine Normand-Marconnet is a lecturer and current convenor of French Studies at Monash University, Melbourne, Australia. Since 2015 she has directed the Intercultural Communication program taught across different campuses of Monash University (Australia, Italy and Malaysia). Her research interests include innovative curriculum design for teaching and assessment, second language acquisition, language policy, and transnational education.

\section{Joseph Lo Bianco}

Dr Joseph Lo Bianco is Professor of Language and Literacy Education at the University of Melbourne, Australia. He is also Research Director for the UNICEF Language Policy and Peacebuilding Program in Southeast Asia, specifically Malaysia, Myanmar and Thailand. His principal research interest is in Italian language and culture studies, Asian education, language policy and planning, bilingual studies, and connections between social cohesion and language issues. 


\section{University Library}

\section{- M M N E R VA A gateway to Melbourne's research publications}

Minerva Access is the Institutional Repository of The University of Melbourne

Author/s:

Normand-Marconnet, N;Lo Bianco, J

Title:

The Common European Framework of Reference down under: A survey of its use and nonuse in Australian universities

Date:

2015-10-01

Citation:

Normand-Marconnet, N. \& Lo Bianco, J. (2015). The Common European Framework of Reference down under: A survey of its use and non-use in Australian universities. LANGUAGE LEARNING IN HIGHER EDUCATION, 5 (2), pp.281-307. https:// doi.org/10.1515/cercles-2015-0014.

Persistent Link:

http://hdl.handle.net/11343/122075 